\title{
The Papel of the Municipal University Center of Trinidad in the Strategic Planning of the Agricultural Cooperative Sector in the Territory
}

\author{
Delvis Valdés Zayas*, Clara Isabel Suárez Rodríguez, Eduardo Águila Turiño \\ Department of Development, Municipal University Center of Trinidad, Trinidad, Cuba
}

Email address:

delvis@uniss.edu.cu (D. V. Zayas)

${ }^{*}$ Corresponding author

To cite this article:

Delvis Valdés Zayas, Clara Isabel Suárez Rodríguez, Eduardo Águila Turiño. The Papel of the Municipal University Center of Trinidad in the Strategic Planning of the Agricultural Cooperative Sector in the Territory. American Journal of Plant Biology.

Vol. 4, No. 4, 2019, pp. 110-113. doi: 10.11648/j.ajpb.20190404.19

Received: January 18, 2019; Accepted: March 20, 2019; Published: November 22, 2019

\begin{abstract}
The strategic thinking of companies is the coordination of creative minds within a common perspective that allows a business to move towards the future in a way that is satisfactory for all. The purpose of strategic thinking is to help explore the many future challenges, both predictable and unpredictable, rather than preparing them for a probable single tomorrow. Among the main latent difficulties that constitute a current brake to achieve the proposed objectives to achieve food sovereignty of the Trinidad Municipality, Cuba, based on the respect and conservation of the environment, we can cite: bad agro-economic management, indiscriminate use of agricultural inputs, ignorance of producers and professionals of sustainable production technologies, soil degradation, ignorance of botany and plant breeding of frequently planted crops, poor quality or insufficient availability of the seeds of seeds and bacteria used, ignorance and violation of current agricultural legislation, territorial agricultural ordering outside the real context presented by the municipality, among others. Elements that in one way or another have to do with the insufficient training of professionals and workers in the agricultural sector in the territory. The present work proposes a design and implementation of training actions in the agricultural sector of the territory that allow to reach sustainability standards in the same, starting from a joint action between the Municipal University Center of Trinidad and the Municipal Delegation of Agriculture, exposing already the first results of this training, which are taxed to increase the efficiency of work in the agricultural sector of the territory.
\end{abstract}

Keywords: Taining, Territory, Strategy, Efficiency and Elevation

\section{Introduction}

The story shows how companies have evolved according to the transformations that occur in their technological, socioeconomic and political environment. If the company wants to survive, it must continue adapting, anticipating and responding to changes in its environment. This will be vital to their ability to adapt and respond as the quality of their management. This requires a new approach to the directive: a strategic management approach $[2,14,15]$.

One of the advantages of this analysis model is that it can be applied in any management situation, type of company (regardless of its size and activity) or business area. The first step we must take is to describe the current situation of the company or department in question, identify the strategies, the changes that occur in the market and our capabilities and limitations. This will serve as the basis for a historical, casual and projective analysis [8].

The SWOT helps to consider the actions we should take to take advantage of the opportunities detected and eliminate or prepare the company against threats, being aware of our weaknesses and strengths. Once the objectives are set -which must be hierarchical, quantified, real and consistent-, we will choose the strategy to reach them through marketing actions [9-10].

The cooperative of agricultural Production (CPA) "13 of March" of the municipality of Trinidad immersed in the exigencies that reports a world in constant change and being 
a base producing structure with favorable results in the territory has given quantitative jumps and Qualitative in the integration and implementation of its management system, however, there has not yet been a systematic and sufficiently scientific work that combinees and compromises all its potentials, which necessitates a thorough study of the situation Present to draw the main strategic lines until the year 2016 surpassing dialectically the achieved until 2014. Therefore, at the request of the municipal delegation of the agriculture in Trinidad, a group of specialist of the Municipal University Center of Trinidad is entrusted to carry out a study that allows to establish a diagnosis and to establish a plan of actions that per Mita put in the hands of the management team of this sector an instrument that really guides their actions, translating the same in goals and strategies for all levels and areas of activity.

\section{Methods}

\subsection{Characterization of the CPA 13 March}

The CPA 13 of March of the municipality Trinidad is located in the rural settlement "La Paloma" on the road that links to this municipality with the provincial head Sancti Spiritus between the settlements Manaca Iznaga and Accusy. It has a total area of $540.69,63.1 \%$ of which is dedicated to the exploitation of various crops. The remaining area is dedicated to forestry production and extensive cattle ranching (vaccine and ovine-caprine).

Founded in 1981, in its origins grouped a number of peasants with family ties that recognized the advantages of this type of association. In 2005 after the restructuring process carried out in the Ministry of Sugar, the unit assumed development strategies taking advantage of the potentialities and experiences accumulated in its years of existence and joined the programs Agri-foodstuffs demanded by the Cuban state.

One of the most significant details in this regard is the introduction of the covered crop technique for the production of vegetables mainly tomato, cucumber and peppers. Supported by non-governmental organizations and the Municipal Directorate of the National Association of Small farmers in Trinidad, it has 3 houses of cultivation that constitute their main strength in the agricultural branch. The CPA has initiated the incorporation into the new direct sales options to the local tourism sector with excellent results from the second half of 2012 .

Currently it has 121 associates of them 24 women and 97 men. The Board of Directors is made up of three representatives, including its President, who has been in office since 2003.

The number of workers associated with CPA increases in harvest times when community workers are hired for a given time.

\subsection{Proposal of the Strategic Model}

To improve the performance of this cooperative is proposed the strategic model taken from the resolution of the Council of State in 1997 which comprises three basic moments for its implementation.

The moment of diagnosis includes the application of instruments and their analysis, to try to know the current situation of the production unit, emphasizing the fulfillment of its social object, its mission, the shared values and the SWOT analysis.

\subsection{Mission Statement}

Supported by the proposed model; It is necessary that the CPA " March $13^{*}$ has as its mission to contribute to the achievement of the food security of the municipality Trinidad supported in the internal potentialities, the sustainable development, and the competitiveness of the agricultural sector for the benefit of the society and other Customers.

\subsection{Strategic Analysis}

The cooperative has mastery of the main demographic tendencies of the population settlements that surround it as well as of the urban areas with which it has compromised deliveries of agricultural products on a regular basis; The aspect shown below as a necessary analysis [16].

The strategy in this phase is conceived as the result of the conjunction of three elements: The environment, the resources of the organization and the expectations of the different "Stakeholders [11-12]

Micro Environment: (Analysis of the 5 forces of Porter).

\section{Results}

\subsection{Threat of Entry of New Competitors}

The approval and implementation of Decree Law 300 on land for the enjoyment has generated an increase in the number of local agricultural producers. The existence of other agricultural base units and a state-owned enterprise constitutes the basis of the competence of the entity under study. However, the cooperative "March 13" possesses particular conditions that differentiate it from these competitors within which they emphasize the fact of having seven houses of protected cultivation that guarantees the production of vegetables and vegetables of high quality All year round.

Rivalry between competitors: the internal potential of the cooperative, its productive prestige and the sense of belonging of its partners to the specific characteristics of its competitors, evidence that they are not yet considered a potential danger For the entity.

Power of negotiation or influence of suppliers: the cooperative has the power to negotiate directly with the suppliers of inputs and resources specific to the agricultural activity. The procedures of material assurance are made by the address itself. The main suppliers that are counted are: the agricultural Supply Company, the Provincial Seed Company and the Municipal Agricultural Company. In recent years the negotiating power has been affected for the acquisition of 
very specific products that are marketed in special conditions and in convertible currency, CUC, by the state centralization of prices.

Influence or power negotiator of users [3]: There are possibilities to be able to negotiate with the users, mainly those state institutions like the tourist, incorporated recently to the commercialization with the cooperative, although in all the cases the negotiation with these and other users Legal is subject to the domestic regulations and policies of the country for the marketing activity of agricultural products.

Natural users (population) have no influence or negotiating power [7].

Threat of entry of substitute products: the entry of new substitute products is not currently envisaged; Although that possibility is not really dismissed and this particular aspect is followed up to try to give a timely response if necessary.

Let us take into account the results generated by the application of a SWOT matrix, to better understand how necessary is the search for a strategic solution for the future of this cooperative [3].

\subsection{Threats}

a) Blocking the island that makes it impossible to access markets with advantageous costs for the national economy.

b) Non-existence in the territory of companies specializing in the production and marketing of seeds and cattle of high genetic quality.

c) The climatic situation of Trinidad characterized by the increase of the temperatures and the decrease of the rainy periods.

d) Increase of the basic inputs necessary to develop the agricultural activity (seeds, chemical products, tools, clothing and footwear as well as machinery and spare equipment for them).

e) Little social recognition of the role of the agriculture as economic activity in the municipality.

\subsection{Opportunities}

a) To be located in a municipality with great development of the tourist activity that demands large volumes of agricultural products.

b) Inefficient performance of the Municipal collection company and other production structures that do not guarantee the fulfillment of the supplies of agricultural products for the population and state institutions.

c) Local government's interest in improving the current situation of the agricultural activity in Trinidad.

d) International support provided by NGOs that provide means and technical resources that are not within the reach of the unit. Eg: Proyecto Palma.

e) Promulgation of new government regulations that cover the frameworks of action of the different areas.

\subsection{Weaknesses}

a) Low natural fertility of soils in agricultural holdings within the CPA.

b) Transportation limitations available for technical obsolescence, fuel shortages and spare parts.

c) Few levels of updating of technical knowledge in the different agricultural specialties.

d) It does not have foreign exchange financing for the purchase of inputs (office supplies for example).

e) You do not have email or other similar communication technologies: Facebook, Intranet, Internet., ect.

f) Lack of a specialist trained to attend to economic activity and internal control.

Results from cross-impact matrix analysis.

Strengths - Opportunities 34 strengths - threats 35

Weaknesses - Opportunities 67 weaknesses - Threats 42

Source: Self-elaboration

\subsection{Strategic Problem}

If the entity is well identified as its main threat, the increase of the basic inputs necessary to develop the agricultural activity; And if the weaknesses of the low natural fertility of soils in agricultural holdings within the CPA are not attenuated or resolved, and they do not have foreign exchange financing for the purchase of inputs; In spite of having strengths such as: prestige of the unit before the administrative authorities and having shelters of protected cultivation that guarantee stability in the production of vegetables and fresh vegetables; It will not be possible to take advantage of the opportunities that represent being located in a municipality with great development of the tourist activity that demands large volumes of agricultural products and the interest of the local government to improve the current situation of the Agricultural activity in Trinidad.

\section{Discussion}

If we compare the results of the present work with results of other works carried [9], out in the subject in question, then it can be stated that if the entity has identified as its main threat the increase in the basic inputs needed to develop the agricultural activity; and if the weaknesses that suppose the low natural fertility of the soils in agricultural holdings within the CPA are not mitigated or resolved and do not have financing in foreign currencies for the purchase of inputs; despite having strengths such as: prestige of the unit before the administrative authorities and having protected cultivation houses that guarantee stability in the productions of fresh vegetables and vegetables; the opportunities that represent being located in a municipality with great development of the tourist activity that demands large volumes of agricultural products and the interest of the local government to improve the current situation of the agricultural activity in Trinidad can not be taken advantage of [3-4].

Then, in correspondence with the theoretical elements previously analyzed, it is proposed that the cooperative must assume a reorientation strategy that allows it to minimize the weaknesses and consequently make the most of the 
opportunities; emphasizing the proposed strategic direction to mitigate the negative impacts of its reorientation and insertion in the new conditions, for a better productive performance in sustainable development; that allow him to reach the proposed goals based on the necessary changes that the entity should take into account in this regard. [1]

\section{Conclusions}

The review and timely analysis of the extensive bibliography consulted served as a support to build a theoretical-reference framework, which allowed the best understanding of the terms and definitions addressed.

The selected strategic model traverses three fundamental moments: diagnosis, projection and execution and control; These are closely related and guarantee the correct future projection of the entity, aimed at achieving its goals. Since it allowed the elaboration of the strategic plan of the production unit according to its actual situation; This will then be reversed in the optimization of the productive results of this one in the short, medium and long term, once the final implementation is decided.

In correspondence with the theoretical elements previously analyzed, it is stated that the cooperative must assume a reorientation strategy that allows it to minimize the weaknesses and consequently make the most of the opportunities; emphasizing the proposed strategic direction to mitigate the negative impacts of its reorientation and insertion in the new conditions, for a better productive performance in sustainable development; that allow him to reach the proposed goals based on the necessary changes that the entity should take into account in this regard.

Submit for discussion and analysis on the board of Directors of the CPA "March 13", the results of this research to serve as a basis for subsequent decision making. The CPA "March 13" continue with this investigative line which will provide improvement in the aspects related to its strategic projection and consequently, an improvement in its integral results.

\section{References}

[1] Collective of authors. Strategic Management compilation. Faculty of Economics, University of Havana, Cuba, 2001.

[2] González Toledo, Alfredo O. Redesign and implementation of the management strategy of the basic unit of cooperative production Siguaney. Thesis in option to the academic degree of Master in Management, center of study in advanced techniques of management, Faculty of Accounting and Finance, University of Sancti Spiritus "José Martí Pérez", 2007.

[3] Koontz, H. Elements of Administration, 3rd edition, S/Editorial, 2003.

[4] Kotler, P. Marketing direction. Editorial Pearson Education, S. A. 10th ed. España, 2000.

[5] Kotler, P. Marketing Management. Prentice Hall, 2005.

[6] Mc Onasiy, J. Marketing: A global approach. Editorial Mc Graw-Hill de Management. 13th ed. Spain. 2000.

[7] Moya Fernandez, Roxana. Proposal of the commercial strategy of the Cultural event International Festival of the new Latin American cinema. Thesis in option to the degree of degree in tourism. Faculty of Tourism, University of Havana, Cuba, 2010.

[8] Born Montagne, Juan a. Design and implementation of a strategy to assess sales in the UBPC-south of Jíbaro. Thesis in option to the academic degree of Master in Management, center of study in advanced techniques of management, Faculty of Accounting and Finance, University of Sancti Spiritus "José Martí Pérez", 2007.

[9] Pérez Oliva, Jany. Proposal of actions to improve the marketing of the Integral company Zapata Peninsula of the hotel group Cubanacán for the period 2010-2015. Thesis in option to the degree of degree in tourism. Faculty of Tourism, University of Havana, Cuba, 2010.

[10] Menguzzato, M. and Renau, J. J: The strategic direction of the company. Barcelona: Ed. Ariel, 1991.

[11] Term in English of owners of risk, which is conceived as the people who they assume the power in the company and, therefore, the risk.

[12] Johnson G. and Scholes, K. Strategic direction. Madrid: Ed. Prentice Hall, 1996.

[13] The strategic direction: a competitive advantage. In Line (https://www.monografias.com/trabajos65/direccionestrategica/). 2018.

[14] Guerras Martín, L. A.; Navas López, J. E The strategic direction of the company. Theory and applications ( $4 .^{\mathrm{a}}$ ed., cap. 1, 2, 3). Madrid: Thomson-Civitas, 2007.

[15] Navas López, J. E.; Guerras Martín, L. A. Cases of strategic management of the company ( $4 .^{\mathrm{a}}$ ed.) (Caso 3: "Iberdrola, an ethical and social commitment"). Madrid: Thomson-Civitas, 2008.

[16] Guerras Martín, L. A. L and Col The nature of strategic management. In Line (http://cv.uoc.edu/annotation/286358c6568795c01a76cac86d6 9262e/495155/PID_00144800/modul_1.html), 2019. 